Revista Iberoamericana, Vol. LXXIX, Núm. 243, Abril-Junio 2013, 415-430

\title{
LA PROLE DE VIRGILIO: \\ VAIVENES DE LA RECEPCIÓN DE VIRGILIO PIÑERA EN CUBA
}

\author{
POR \\ RAFAEL RoJAs \\ CIDE
}

El poeta, narrador, dramaturgo y ensayista Virgilio Piñera murió en La Habana, en 1979, marginado y aborrecido por buena parte del medio intelectual cubano, entonces regido por una ideología marxista-leninista, formulada en términos muy similares a los de la Unión Soviética desde la época de Stalin, y vertebrado en torno a autores canónicos como Nicolás Guillén y Alejo Carpentier, comunistas antes y después del triunfo de la Revolución de 1959. Piñera, en cambio, además de homosexual y ateo, había sido crítico del marxismo y el comunismo antes de 1959 y del dogmatismo y la intolerancia en las dos décadas que vivió bajo el socialismo insular.

A pesar de su rareza en un campo intelectual predominantemente católico y burgués, antes de la Revolución, y marxista y comunista después de la misma, Piñera fue un escritor fundamental de la vida literaria cubana entre 1941 -año de publicación de su primer poemario, Las furias, en la editorial de la revista Espuela de plata, dirigida por sus amigos José Lezama Lima, Guy Pérez Cisneros y Mariano Rodríguez- y 1969, cuando al premio Casa de las Américas, otorgado por su pieza teatral Dos viejos pánicos (1968) el año anterior, se sumó la edición de La vida entera (1969), su último cuaderno de poesía publicado, literalmente, en vida.

La centralidad de Virgilio Piñera en el campo intelectual cubano durante aquellas tres décadas no sólo estuvo asegurada por una provocadora y nutrida obra poética, narrativa y ensayística -el poemario La isla en peso (1943), la novela La carne de René (1952), los relatos de Cuentos fríos (1956)-, o por una constante presencia en la escena teatral cubana, a pesar de los catorce años de su exilio intermitente en Buenos Aires, sino también por una intervención sostenida en los debates literarios de la isla, recogidos por publicaciones como Orígenes, Gaceta del Caribe y Ciclón, antes de 1959, y Lunes de Revolución, La Gaceta de Cuba y Unión después de la llegada de Fidel Castro al poder.

En las páginas que siguen quisiera reconstruir, a grandes rasgos, el proceso de reubicación de Virgilio Piñera en el canon cubano que inicia a fines de los años ochenta del pasado siglo. La principal presión a favor del rescate de Piñera fue ejercida, como veremos, por varios escritores desde la isla -Antón Arrufat, Abilio Estévez, Antonio 
José Ponte, Víctor Fowler, entre otros- que admiraban al autor de La isla en peso y que reaccionaban críticamente a la reivindicación oficial de Orígenes, bajo los criterios estéticos e ideológicos de Cintio Vitier, figura que ocupó, en las últimas décadas del siglo xx, un lugar central en el aparato de legitimación del socialismo cubano.

La visión nacionalista, católica y homofóbica de Vitier sobre la literatura de Piñera -plasmada, por lo menos, en cuatro textos suyos: la reseña sobre Poesía y prosa (1944), en el número de la primavera de 1945 de Orígenes, las semblanzas de Piñera en las antologías Diez poetas cubanos (1948) y Cincuenta años de la poesía cubana (1952) y las seis páginas que le dedica en Lo cubano en la poesía (1958)- volvió a circular en La Habana de los noventas, a través del propio Vitier o sus discípulos, generando la reacción de la prole virgiliana. La identidad genealógica de esa prole, heterogénea en sus poéticas y políticas, se formó, pues, dentro de una atmósfera de réplica discursiva a la canonización oficial de José Lezama Lima y Orígenes, promovida por el propio Vitier y el Ministerio de Cultura de la isla.

Este ensayo es una breve reconstrucción de los debates sobre la obra de Piñera, en el campo intelectual cubano, durante las dos últimas décadas. Pero quisiera ser también una constatación del legado vivo de Piñera en la literatura contemporánea cubana, especialmente, en la nutrida, variada y, a la vez, congruente obra de Antón Arrufat (Santiago de Cuba, 1935). La poesía, la narrativa, el teatro y los valiosos ensayos sobre literatura cubana de los siglos XIX y xx, del autor de Los siete contra Tebas (1968), son, tal vez, el mejor indicio de la pervivencia de una poética en sus sucesores.

No sé si Arrufat asuma una inscripción en el legado de Piñera, similar a la que declaró Severo Sarduy en relación con Lezama-“inscribo, en esta patria que es la página, en minúsculas y sobre una cifra, mi paso por la Era Lezama” (en Lezama Lima 112)-, pero su obra es, en buena medida, una prueba ontológica de la existencia de Piñera como referente de la literatura cubana contemporánea. La "luz espejeante" de Piñera, para usar la fórmula que Enrico Mario Santí aplica a la recepción de Octavio Paz en la literatura mexicana de hoy, se refleja en los textos de Antón Arrufat.

\section{LA EXTRAÑA LATITUD}

En un sintomático ensayo, titulado Virgilio Piñera: entre él y yo (1994), Antón Arrufat fecha en 1986 el primer homenaje póstumo a Virgilio Piñera, en Cuba, siete años después de su muerte. En ese texto, mitad memoria, mitad relectura, como los buenos ensayos, Arrufat reconstruía las tertulias de los años setentas en las que se reunían Abelardo Estorino, Olga Andreu, José Triana, el propio Piñera y otros intelectuales marginados a leer poesía y teatro. La descripción que hace Arrufat de aquellos encuentros permitiría imaginar no sólo el tipo de sociabilidad intelectual que se producía en los bordes de la ciudad letrada de la isla sino también la adaptación de la escritura a un orden social y político excluyente:

\footnotetext{
Revista Iberoamericana, Vol. LXXIX, Núm. 243, Abril-Junio 2013, $415-430$
ISSN 0034-9631 (Impreso)
} 
Situados por la burocracia y la dirigencia política del país en esa “extraña latitud” de la muerte en vida, estas tertulias poseían un valor único: nos devolvían-momentáneamenteel ser. Al reunirnos como lo que realmente éramos, al reconocernos entre nosotros, la "extraña latitud” impuesta desaparecía por unas horas. Estas reuniones nos proporcionaban, además, la felicidad de estar juntos, conversar, leernos en nosotros mismos y en los demás. (Virgilio 45)

Más adelante, Arrufat argumentaba que aquella “extraña latitud” de la muerte civil se convertía, inevitablemente, en una condición de posibilidad para la escritura:

Y era otra dicha comprobar que, pese a la marginación social del momento, la energía creadora no había sido extinguida. Durante esas lecturas estábamos justificados ante nosotros mismos, en virtud del reconocimiento de los demás. Fluía nuestra única y verdadera vida, centrada en la creación literaria. Bastaba con que el resto de los asistentes a la tertulia nos escuchara, para que se mantuviera activo y real nuestro ser. (Virgilio 45-46)

La "extraña latitud” comenzaría a dejar de ser tal en 1986, no sólo para el propio Piñera, en la muerte, sino también para Antón Arrufat mismo, en vida. A partir del año siguiente, la obra de Piñera comenzó a ser editada regularmente en la isla: en 1987 la editorial Letras Cubanas publicó dos libros de cuento: Un fogonazo y Muecas para escribientes. En 1988 apareció el volumen de poesía inédita, Una broma colosal (La Habana, Unión), con prólogo de Arrufat, en el que se rastreaba la presencia de José Jacinto Milanés, Juan Clemente Zenea y Julián del Casal en la última lírica piñeriana. En 1992 vieron la luz dos libros más de la narrativa inédita de Piñera en La Habana: Algunas verdades sospechosas (Abril, 1992), con prólogo de Salvador Redonet, y El viaje (La Habana, Unión, 1992), con prólogo de Mirta Yáñez. Con la edición del Teatro inédito (La Habana, Letras Cubanas, 1993) y de la poesía casi completa en el volumen La isla en peso (La Habana, Unión, 1998), también prologado por Arrufat, una buena parte de la obra de Piñera quedó rescatada editorialmente para el público de la isla.

En esos mismos años, también la obra narrativa, poética y dramatúrgica de Antón Arrufat -el mismo perfil multigenérico de Piñera-comenzó a ser reivindicada en la isla. Tras la publicación de la novela, catorce años vetada, La caja está cerrada, en 1984, que obtuvo el Premio de la Crítica en ese año, la literatura de Arrufat comenzó a ser regularmente editada: en 1986 apareció una compilación de su poesía, bajo el títu1o La huella en la arena; en 1987, su extraordinario volumen de ensayos Las pequeñas cosas; en 1988, los relatos de Qué harás después de mí, y entre este último año y 1995, varias piezas de teatro como La tierra permanente, Cámara de amor y La divina Fanny. El citado ensayo Virgilio Piñera: entre él y yo (1994) reflejaba esa salida a la luz, toda vez que Arrufat no sólo exponía, públicamente, la estética de su maestro y amigo sino también su homosexualidad (50).

Revista Iberoamericana, Vol. LXXIX, Núm. 243, Abril-Junio 2013, $415-430$
ISSN 0034-9631 (Impreso) 
Aunque tal vez sea el primogénito de aquel linaje, Arrufat no es el único escritor cubano que, de los noventas para acá, ha reclamado para sí el magisterio y la poética de Piñera. Abilio Estévez, también dramaturgo, poeta, narrador y ensayista, también amigo y discípulo de Piñera, ha dejado más de un testimonio de su pertenencia a esa estirpe. Su obra de teatro La verdadera culpa de Juan Clemente Zenea (La Habana, Ediciones Unión, 1987) debe más a la visión piñereana de Zenea, plasmada en Una broma colosal (1988), que al ensayo Rescate de Zenea de Cintio Vitier, aparecido el mismo año de la obra teatral de Estévez, también en la editorial Unión. En su Inventario secreto de La Habana (2004), Estévez da cuenta de su relación intelectual con Piñera y de la marca del autor de La carne de René en su propia literatura.

Tras su muerte, Virgilio Piñera comenzó a sobrevivir como figura de culto y como personaje literario. Dos poetas cubanos, uno desde la isla, César López, y otro desde el exilio, Severo Sarduy, le dedicaron poemas. El primero, en "Truenos en el Olimpo porque Virgilio Piñera ha muerto", escribió "no hubo toque ni ritmos escabrosos/ como lo presintiera (mulatos fálicos) (falos muláticos),/ mulaticos con falos prominentes, prominencia/ en la Mesopotamia y en Camagüey,/ en Santiago, en Buenos Aires y en Guanabo” (Antología 223). Sarduy, desde París, pidió irónicamente la canonización de Virgilio Piñera, escritor ateo y anticlerical: "insisto empero/ para que tenga sitio en los altares/ este mártir de arenas insulares./ Por textual, su milagro verdadero/ dio presa fácil a los cabecillas/ y a los sarcasmos que, de tanto en tanto,/ interrumpen las furias amarillas,/ las madres del exilio y del espanto” (Antología 264).

Otro joven poeta habanero, Alberto Acosta Pérez, escribió un "Poema por Virgilio Piñera”, dedicado a Antón Arrufat y a Abilio Estévez, que seguía el formato de la ofrenda de los juegos florales, en la que el maestro recitaba y el discípulo lo coronaba. Al final, el espectáculo adoptaba la atmósfera de una farsa, como las propias obras piñerianas, en la que el homenajeado no era un héroe o un Cristo sino una inversión de todo rol paradigmático. El poema de Acosta Pérez era bastante emblemático de la recepción de Virgilio Piñera en La Habana de los ochentas: una recepción portadora de otra política intelectual, aquella que, en lugar del compromiso con el poder, demandaba el compromiso con el arte de la escritura:

Tú reías azorado: "todo esto es solo polvo de la vida. Vamos, hagamos un opening fastuoso". Leías declamando tus poemas.

En realidad todo me lo sugirió el arco voltaico de tus ojos:

"la libertad es una paradoja, un país de nadie

déjame olvidar esa palabra”.

Aquí traigo bellas flores blancas para Kavafis.

Jamás nadie pagó tanto.

Y para ti, una rosa de miedo, una rosa genuflexa, la flor de las alucinaciones,

Revista Iberoamericana, Vol. LXXIX, Núm. 243, Abril-Junio 2013,
ISSN 0034-9631 (Impreso) 
porque tú no eres la pureza y ahora somos dos

los que nos confesamos en tus versos. (Antología 437)

En aquellos mismos años -fines de los ochentas y principios de los noventas- en que comenzaba a reeditarse a Virgilio Piñera en La Habana, dos importantes escritores exiliados, Guillermo Cabrera Infante y Reinaldo Arenas, vindicaron también la literatura del gran dramaturgo cubano. Cabrera Infante había escrito su extraordinaria evocación de Lezama y Piñera, “Tema del héroe y la heroína”, en 1980, a raíz de la muerte del segundo. Ese texto reapareció, corregido y ampliado, en Mea Cuba (1993), la colección de los ensayos de Cabrera Infante, y luego en Vidas para leerlas (1998). Reinaldo Arenas, por su lado, incluyó una semblanza de Piñera en Antes que anochezca (1992), que compartía con la de Cabrera Infante una insistencia en cuatro elementos de la obra del narrador de Cuentos fríos: la homosexualidad, el anticomunismo, el ateísmo y la entrega en cuerpo y alma a la literatura (105-108).

La recuperación del legado de Virgilio Piñera, su salida de aquella "extraña latitud” de la muerte civil, de que hablaba Arrufat, se convirtió en un asunto vital para las nuevas generaciones de escritores de la isla. Abilio Estévez, tal vez el más joven de los escritores cubanos que llegó a tener una relación con Piñera en vida, no fue el único que salió en defensa de su amigo y maestro en aquellos años. Víctor Fowler dedicó un agudo comentario a la novela La carne de René en su libro La maldición. Una historia del placer como conquista (1998), un conjunto de ensayos sobre homosexualidad y homoerotismo en la construcción nacional cubana (73-94). Antonio José Ponte, escritor que por entonces no rebasaba los treinta años, y que no conoció a Piñera, escribió varios artículos y ensayos en los que propuso una relectura de Julián del Casal y Virgilio Piñera, como autores cuya escritura estaba más referida a una estética que a una ideología.

Aquellos textos, "El libro perdido de los origenistas" (La gaceta de Cuba, 1992), “Casal contemporáneo” (La Habana Elegante, 1993), La lengua de Virgilio (Matanzas, Ediciones Vigía, 1993), "La Habana de Paradiso” (Lagaceta de Cuba, 1994), “A propósito de un plato antiguo” (La revista del Vigía, 1994) y "Por los años de Orígenes” (Unión, 1995), reunidos luego en el volumen El libro perdido de los origenistas (2002), proponían una crítica del origenismo oficial, construido por las visiones homogeneizantes del legado literario de aquella generación establecidas por Cintio Vitier y sus discípulos. La crítica de Ponte encaraba frontalmente el mito de la "teleología insular", en tanto sustrato de una asimilación de Orígenes al discurso legitimador de la Revolución Cubana. Lo más cuestionable de esa operación, según Ponte, no era la propia inserción de Vitier en los aparatos ideológicos del Estado cubano sino la instrumentación política del legado de José Martí y José Lezama Lima, por un lado, y el ascenso, a rango oficial, de su virtual excomunión de Virgilio Piñera y Lorenzo García Vega de la ciudad letrada insular.

Sin hacer demasiado visible su adscripción a la imagen literaria del siglo xix cubano, desarrollada por Piñera y Arrufat en sus ensayos, Ponte se declaraba más contemporáneo

Revista Iberoamericana, Vol. LXXIX, Núm. 243, Abril-Junio 2013, $415-430$
ISSN 0034-9631 (Impreso) 
de Casal que de Martí (33-41). Luego desmenuzaba críticamente los juicios de Vitier sobre Piñera, con el fin de refutar la idea de que en la literatura piñeriana se plasma algún “testimonio falseado de la isla” (43-52). En su relectura de Los años de Orígenes de Lorenzo García Vega, Ponte hallaba una contrahistoria de la experiencia origenista que le permitía hacer girar su crítica, no en torno al legado de Orígenes, sino en torno a la versión vitieriana del mismo, suscrita por el Estado insular en los noventas (73-82) Finalmente, Ponte desembocaba en el meollo del debate origenista: la diferencia entre las nociones de "teleología insular" en la poética de Lezama y en la política de Vitier (90-104).

Casi al mismo tiempo en que aparecían, reunidos en México, los ensayos de Ponte, en La Habana, un jurado compuesto por Luisa Campuzano, Luis Álvarez y Carina Pino Santos, concedía el Premio Alejo Carpentier al libro La poesía de Virgilio Piñera. Ensayo de aproximación (2001) del estudioso Enrique Saínz. Aunque discípulo de Vitier, Saínz era más flexible en sus juicios sobre el autor de $L$ a isla en peso y reseñaba con elocuencia y entusiasmo la poesía escrita por Piñera en sus dos últimas décadas de vida, entre 1960 y 1979 -décadas que, siguiendo a Arrufat, llama “de la muerte” (131-163). En varias páginas, como aquellas en que comentaba la ejemplar defensa de la homosexualidad que hizo Piñera en su "Ballagas en persona”, Saínz se distanciaba de Vitier, pero en otras reiteraba algunos de los tópicos del nacionalismo católico vitierista.

Los momentos en que Saínz restablece los juicios de Vitier sobre Piñera no pasaron inadvertidos a la lectura de Víctor Fowler y Antonio José Ponte. Ambos reconocían la mayor hospitalidad con que Saínz se acercaba a la poética de Piñera, pero no dejaban de señalar que algunas frases, como Piñera "no pudo ver, en la historia cubana del siglo XIX ni en la obra de los grandes fundadores de la nación (Caballero, Varela, Luz, Martí), el país posible” o Piñera careció de “sentido de futuridad” o no ofreció “ninguna propuesta de edificación”, suscribían aquel dictum aduanero de Vitier, plasmado en Lo cubano en la poesía y en Ese sol del mundo moral, que colocaba al autor de Cuentos fríos fuera de los límites morales y poéticos de la "cubanía” (Ponte, "Reclamaciones” 1-3; Fowler, “Otra” 16-28).

La reubicación de Piñera en el centro del canon avanzó, también, fuera de la isla. La edición de los Cuentos completos (1999), en Alfaguara, prologados por Arrufat, colocó a Piñera, junto a Cortázar o Monterroso, en la primera línea de la ficción corta latinoamericana del siglo xx. Ese mismo año, el crítico Carlos Espinosa Domínguez coordinó un homenaje a Piñera en la importante revista exiliada, Encuentro de la cultura cubana. Tres años después, la crítica cubana, radicada en Puerto Rico, Rita Molinero, reunió en un volumen 35 estudios sobre el autor de La isla en peso, entre cuyos autores no sólo figuraban algunos amigos y admiradores de Piñera como el propio Arrufat, Reinaldo Arenas y Severo Sarduy, sino varios escritores cubanos, de diversas generaciones y poéticas, como Leonardo Padura, Eliseo Alberto, Jesús J. Barquet,

Revista Iberoamericana, Vol. LXXIX, Núm. 243, Abril-Junio 2013, $415-430$
ISSN 0034-9631 (Impreso) 
Virgilio López Lemus, Madeline Cámara, José Quiroga, Francisco Morán, Carlos Alberto Aguilera o Jesús Jambrina.

Cuando, a mediados de la última década, aparecieron fuera de la isla Virgilio Piñera en persona (2003) de Carlos Espinosa -también editado en La Habana-, valiosa miscelánea documental, Los límites del origenismo (2005) de Duanel Díaz, el mejor estudio sobre la recepción de los escritores de Orígenes en la isla, y Everythig in Its Place. The Life and Works of Virgilio Piñera (2006) de Thomas Anderson, hasta ahora la más completa biografía del autor de Electra Garrigó, ya Virgilio Piñera había salido de la exclusión a que lo habían relegado la crítica marxista y católica de la isla y buena parte de la crítica latinoamericana y cubanoamericana. A partir de entonces, Piñera comenzaría a recuperar su vida como obra referencial de los estudios literarios y, también, como personaje de la propia literatura cubana. El Piñera que escribe a su amigo José Rodríguez Feo, desde el Buenos Aires de inicios de los cincuentas, en la novela Fumando espero (2003) de Jorge Ángel Pérez y el que conmueve la escena teatral habanera, un poco después, en Esther en alguna parte (2005) de Eliseo Alberto, hablan ya de la sobrevida de un maestro en las ficciones de sus discípulos.

En 2009, la revista española República de las letras, que dirige Andrés Sorel, quiso dedicar un número a Piñera, y encontró que una veintena de escritores cubanos (Pablo Armando Fernández, Reinaldo Montero, Damaris Calderón, Gerardo Fernández Fe, Margarita Mateo, Jorge Luis Arcos, Omar Valiño, entre otros), de todas las generaciones y residencias, sentían la necesidad de colocar al autor de La carne de René como polo de atracción del campo literario cubano. En la víspera de su primer centenario, Virgilio Piñera parecía tensar un arco de recepción en la literatura de la isla, tan amplio y heterogéneo como el de José Lezama Lima o Alejo Carpentier. El ensayo de David Leyva González, Virgilio Piñera o la libertad de lo grotesco (2010), fue una buena muestra de la vitalidad que conservaba, a un siglo de su nacimiento, el autor de Una broma colosal.

Aún cuando Piñera tiene muchos seguidores en la literatura cubana contemporánea, el vínculo entre el autor de $L a$ isla en peso y las últimas generaciones de escritores de la isla ha pasado, fundamentalmente, por la mediación de Antón Arrufat. La obra de Arrufat es una estación ineludible de una genealogía literaria que conecta a Virgilio Piñera con las literaturas cubanas del siglo xxı. Gracias, en buena medida, a Arrufat, la marca de Piñera se lee en la narrativa de Abilio Estévez y Leonardo Padura, en la poesía de Reina María Rodríguez y Sigfredo Ariel, en la prosa de Jorge Ángel Pérez y Antonio José Ponte y en los ensayos de Víctor Fowler y Jesús Jambrina. Marca migrante o fugitiva, donde no se sabe bien cuándo termina Piñera y comienza Arrufat.

Cuando Marcel Proust tomaba notas para En busca del tiempo perdido organizó sus apuntes en forma de conversaciones con su madre. En aquellas charlas escritas Proust expuso su principal diferencia con la concepción de la literatura del gran crítico francés del siglo xix, Sainte-Beuve. Para Proust, el "yo" de quien escribe era diferente al "yo

\footnotetext{
Revista Iberoamericana, Vol. LXXIX, Núm. 243, Abril-Junio 2013, 415-430 ISSN 0034-9631 (Impreso) 
mundano” del escritor, por lo que el misterio de la escritura debía desentrañarse en el acto solitario frente a la página en blanco y no en la biografía, las ideas o las pasiones del autor (24). Entre otras cosas, Proust le reprochaba a Sainte-Beuve que no distinguiera entre la "conversación" y la "escritura" (25). Antón Arrufat, como veremos, pertenece más a la estirpe de Sainte-Beuve que a la de Proust.

\section{EL ARTE DE LA CONVERSACIÓN}

Alguna vez el poeta León Felipe se preguntó porqué los españoles hablaban tan alto. La respuesta del autor de los Versos y oraciones del caminante rezumaba el aliento de sus propias elegías. Los españoles hablaban demasiado alto, según Felipe, porque la historia los había vuelto enfáticos, obligándolos a proferir tres grandes exclamaciones al mundo: la de Rodrigo de Triana cuando gritó ¡Tierra! en 1492; la del Quijote de Cervantes, en los primeros años del siglo xvII, cuando reclamó ¡Justicia!; y la de millones de españoles en 1936, cuando, al borde del franquismo, advirtieron ¡Ahí viene el Coco! y casi nadie les creyó.

Los cubanos, hijos de españoles, también hablamos muy alto. Pero lo que caracteriza nuestra habla no es tanto el volumen como el tiempo, la velocidad y la prolongación del discurso. El cubano habla rápido y habla mucho. Si nos trasladáramos a las disputas morales del siglo xviII francés, los habitantes de Cuba seríamos discípulos del padre Lamy, a quien se debe un popular manual titulado Arte de hablar, y enemigos de los pocos seguidores del abate Dinouart, autor de un Arte de callar, donde se lee que "antes de aprender a hablar, el hombre debe aprender a callar, ya que en silencio arriesga menos y es más dueño de sí” (43). Como un lector de aquellos moralistas franceses, Antón Arrufat ha hecho de su obra literaria un arte de la conversación a medio camino entre el habla y el silencio.

En el citado ensayo Virgilio Piñera: entre él y yo (1994), Arrufat reconocía que la principal enseñanza aprendida de su maestro era un tipo de conversación, un "intercambio personal" o un "entre", que por momentos adoptaba un tono refutador, de diatriba, pero que al final procuraba una sintonía profunda, resistente a la contradicción. Decía entonces Arrufat que la "conversación de Piñera no era de largas tiradas, monologante ni impositiva”, que "buscaba, por el contrario, la controversia del diálogo, casi siempre rivalizador y competitivo" y que "cuando no encontraba contrincante, languidecía" (21). Ese tipo de conversación, mitad diálogo socrático, mitad querella ilustrada, es muy frecuente en la narrativa y el teatro de Arrufat y reaparece en su reciente ensayo, "Oyendo conversar a Lezama”.

Las primeras presencias del arte de la conversación, en la obra de Antón Arrufat, tal vez haya que encontrarlas en sus tempranas piezas de teatro, El caso se investiga (1957), El vivo al pollo (1961), que mereció un elogio de Juan José Arreola en Casa

\footnotetext{
Revista Iberoamericana, Vol. LXXIX, Núm. 243, Abril-Junio 2013, 415-430 ISSN 0034-9631 (Impreso) ISSN 2154-4794 (Electrónico)
} 
de las Américas, o Todos los domingos (1965), y en las narraciones juveniles reunidas en el volumen Mi antagonista y otras observaciones (1963), que apareció, al igual que algunas de sus obras teatrales, en la mítica Ediciones R. Hay en aquellos primeros textos un cuidado en el trabajo con los diálogos que, probablemente, tenga su origen en el contacto con el mundo de la zarzuela y el teatro en su natal Santiago de Cuba, en compañía de su padre.

Otra de las fuentes importantes del sentido dialógico de los primeros textos de Arrufat, además de la narrativa y el propio teatro de Piñera, fue la cuentística de Julio Cortázar. Arrufat, que compiló y prologó los Cuentos (Casa de las Américas, 1964) de Cortázar, se había familiarizado con la técnica del relato breve puesta en práctica en volúmenes como La otra orilla, Bestiario, Las armas secretas y Final del juego. Como bien señala Mario Vargas Llosa, en su ensayo "La trompeta de Deyá", lo que hacía de Cortázar un escritor realista y, a la vez fantástico o metafísico, con resonancias de James y Poe, de Borges y Kafka, era una “limpidez” y una “depuración” en el estilo que presentaban como "tramas diáfanas" o "mundos sin sombra” historias perversas (19-20). En Piñera y en Arrufat sucede algo similar, aunque sin esa fuga hacia lo fantástico y lo gótico que, por momentos, sucede en la narrativa de Cortázar. Los cubanos, como dice Vargas Llosa, también buscan ese momento en que "la realidad banal comienza a resquebrajarse y a ceder a presiones recónditas, que la empujan hacia lo prodigioso”, pero prefieren quedarse del lado de lo real o de lo absurdo o de ambas dimensiones, a la vez, cuya mezcla aprendieron en el teatro de Beckett, Ionesco y Albee (19).

Esa búsqueda de la banalización de la realidad, y de su aspecto monstruoso o sombrío, dentro de la dialéctica de una conversación, es notable, como decíamos, en toda la obra teatral y narrativa de Arrufat. En su primera novela, La caja está cerrada (1984), que ya estaba escrita en 1970, hay un trabajo sumamente refinado con los diálogos que nos transporta a la sociedad santiaguera de las últimas décadas republicanas. El mundo de clase media del Colegio Dolores, de la Compañía de Jesús, el Club San Carlos y las casas de Vista Alegre es reconstruido, por Arrufat, a través de varios modelos de conversación o intercambio verbal, colocados en el centro de una típica bildungsroman. Todas las variantes coloquiales de la novela convergen en el retrato de la formación intelectual, moral y sexual de Gregorio Ibarra, alter ego del Arrufat niño y adolescente.

La novela abre con un tipo de diálogo, característico de la vida privada hispanoamericana, entre mujeres (Idelina y Regina) de una casa, que se mueven entre la cocina y el portal y cuchichean sobre familiares y conocidos. Luego los tópicos verbales se trasladan al mundo de la música, la zarzuela y la ópera, en las ansiedades de Ana Rosa, la estudiante de piano, y en la evocación de la tiple mexicana Esperanza Iris que cantó La viuda alegre y La duquesa del Bal Tabarín en el Teatro Heredia, frente al parque Aguilera, propiedad del abuelo de Gregorio. Poco a poco el arte de la conversación va adquiriendo espesor intelectual en los diálogos entre Gregorio y el tío Rogelio, un "señor jacobino" que reescribe la historia republicana, mientras la narra verbalmente a

\footnotetext{
Revista Iberoamericana, Vol. LXXIX, Núm. 243, Abril-Junio 2013, 415-430 ISSN 0034-9631 (Impreso) 
su sobrino, hasta llegar a las disputas teológicas entre el Hermano Hernández y el Padre Rector, los maestros jesuitas de Gregorio en Dolores.

En el debate teológico entre ambos sacerdotes, el Hermano personifica la posición de la Patrística -en algún momento cita el famoso "creo porque es absurdo" de Tertulianoy el Rector la de la Escolástica: la vieja pugna medieval entre las enseñanzas de San Agustín y Santo Tomás. Para el Rector, dice Arrufat, "la divinidad era lo más alto, fuerte, bello y misericordioso para el hombre"; para el Hermano, era "admirable e infinitamente horrible, el mysterium tremendum". Dios era para el primero la "bondad suma”, para el segundo, "terror” y “espanto”, algo "incomprensible” e "inefable” (99). Aquella polémica teológica podía trasladarse a cualquier tema, por ejemplo, a la Segunda Guerra Mundial, que los padres jesuitas seguían a través de la radio: el Rector veía la guerra como una "epidemia" que sería erradicada; el Hermano la entendía como un estado natural y recurrente: "habrá un descanso, el hombre realizará sus obras de paz, y cuando esté ahíto y fuerte la emprenderá otra vez contra sus semejantes” (98).

El receso, la calma e, incluso, la terapia de aquellos neotomistas era subir a la azotea del Colegio Dolores y contemplar las estrellas con el Padre Oriol. El observatorio era el lugar donde la modernidad, con su discurso astronómico, se imponía a las querellas medievales y donde la moralidad ignaciana experimentaba una indeseada secularización. Ese choque de lo secular y lo moderno con lo tradicional y lo católico reaparece, en toda su elocuencia, en la maravillosa escena del monólogo de don Lucio, el viejo mambí que se volvió agnóstico durante su lucha contra la monarquía española, sus lecturas de Voltaire y Rousseau y su admiración por Hidalgo y Bolívar, y que, al final de la vida, pide la extremaunción, arrodillado ante el retrato de su devota esposa Clodomira (369372). Don Lucio admite, como única prueba de la existencia de Dios, que su esposa le responda desde el más allá: "ante tanto silencio y desamparo, ¿no sería un consuelo, el mío, creer en la existencia de Dios? Que hay otra orilla donde te alcanza mi voz y puedes reconocerla. Si Dios existe, qué callado” (373).

La segunda novela de Arrufat, que apareció quince años después de La caja está cerrada, se titula La noche del Aguafiestas (La Habana, Letras Cubanas, 2000) y transcurre dentro de una misma conversación, desde la primera hasta la última página. Cuando leemos a los grandes maestros del diálogo, Balzac y Tolstoi, Conrad y Hemingway, saltamos de una plática a otra, guiados por un narrador omnisciente que, a veces, habla más que sus propios personajes. En La noche del Aguafiestas ese narrador, es decir, Antón Arrufat, apenas interviene y cuando lo hace es para insinuar borrosas pinceladas de quienes hablan y escuchan. Como en algunas pinturas de Brueghel, el Joven, aquí los personajes no tienen rostro; sus caras son sus propios parlamentos.

La trama de la novela de Arrufat no es más que el coloquio de cinco amigos, Aristarco Valdés (El Aguafiestas), Jenofonte, Filonús, Licino y Actité, en una noche habanera o, más bien, "hablanera”, como diría Guillermo Cabrera Infante. Y he ahí la primera

\footnotetext{
Revista Iberoamericana, Vol. LXXIX, Núm. 243, Abril-Junio 2013, 415-430 ISSN 0034-9631 (Impreso) ISSN 2154-4794 (Electrónico)
} 
sorpresa: los modelos retóricos de esta ficción no parecen provenir de la narrativa, sino de otros géneros occidentales, como el diálogo antiguo y el drama moderno. Sin mucho pudor, podría afirmarse que La noche del Aguafiestas es una novela neoplatónica. Sus personajes, al igual que los de Fedro o del amor y Critón o del deber, son contertulios que discurren sobre diversos temas: el arte de la relectura, la cocina y las frutas cubanas, las posturas del reposo (sentado, acostado y recostado), la cábala, el amor, la sexualidad, el cosmos, la noche... Siendo quisquillosos, diríamos que esta novela corresponde a lo que Platón llamaba simposio o banquete, es decir, una plática que recorre varios diálogos.

Pero más allá de la retórica, hay un platonismo intelectual, metafísico, en La noche del Aguafiestas, que se proyecta en la reflexión sobre la palabra y el lenguaje, sobre el deseo y el placer. Los cinco personajes de esta novela son criaturas entregadas al acto del decir, como si sólo en la articulación de un discurso encontraran las pruebas ontológicas de sus existencias. Aristarco, el Aguafiestas -personaje que equivale al Sócrates de Platón, maestro perverso- lo formula de un modo rotundo: "callarse significa atentar contra la persona, correr el riesgo de la desaparición” (79). Y más adelante remata con un juicio cercano al último Heidegger, el de la Carta sobre el humanismo (1945), texto clave del neoplatonismo moderno: "hablamos para poseer lo que pensamos, y hasta lo que hemos realizado. Poseemos la acción cuando la contamos, y hasta los sueños, si no se pierden y se apagan. La lengua nos redime del silencio de las tinieblas” (95).

La idea heideggeriana del "lenguaje como casa del ser" se plasma en La noche del Aguafiestas desde el sentido mismo de la "doctrina platónica de la verdad", es decir, desde la certeza de que la palabra invoca el recuerdo y que la memoria consuma el saber. Platón entendía el conocimiento como la anámnesis o reminiscencia de grandes nociones universales (el Bien, la Belleza, el Orden, la Justicia...) que el hombre, a tientas en la penumbra de su caverna, había olvidado. Pues bien, Aristarco Valdés (el Aguafiestas) piensa, como el Sócrates de la República, que "descubrir algo nuevo no es más que recordar algo perdido” y sueña con levantarle a Mnemósine, Diosa del Recuerdo y madre de las nueve musas, una estatua en el Parque de la Fraternidad de La Habana, ya que "sin memoria no habría fraternidad ni tampoco gratitud" (50).

Pero La noche del Aguafiestas no sólo nos remite a Platón en su metafísica, sino también en su erótica, que es indisociable de aquella. Según el Fedro, el saber es amor porque se funda en la posesión de las eidolas o nociones universales que habitan el alma. Los cinco personajes de esta novela también aman por medio de la posesión del otro en el lenguaje. Aristarco desea a Actité, Actité desea a Jenofonte, Licino desea a Aristarco. Sin embargo, la instancia del placer, en los tres casos, se posterga indefinidamente por medio del goce de la pulsión y de su narrativa verbal. No creo, pues, que estos personajes sean onanistas, sino, más bien, practicantes de una erótica de la distancia, de la "evasión corporal”, parecida a la que postula el filósofo francés Emmanuel Lévinas, esto es, el hedonismo intelectual de quienes conocen la finitud del placer y la intensidad del dolor.

\begin{tabular}{l} 
Revista Iberoamericana, Vol. LXXIX, Núm. 243, Abril-Junio 2013, $415-430$ \\
\hline ISSN 0034-9631 (Impreso)
\end{tabular} 
Esta erótica resistente se expresa a cabalidad en los dos monólogos que interrumpen el coloquio de la novela: el de Jenofonte y el de Filonús. Jenofonte, discípulo de Aristarco/ Sócrates, cuenta la historia de su amor con Madame Récamier, la hermosa dama de la Restauración francesa, que reunió en su salón a la intelectualidad selecta de los reinados de Luis XVIII, Carlos X y Luis Felipe de Orleans. Los desvelos de Jenofonte, mulato habanero de fines del siglo xx, no son provocados, naturalmente, por la misma Julie Bernard que amaron Constant y Chateaubriand, sino por una imagen suya: el retrato que le hiciera, siendo ella muy joven, el pintor neoclásico del Imperio, Jacques Louis David.

La historia de amor de Filonús, momento en que la prosa de Arrufat exhibe su consabida elegancia, es aún más reveladora de esta erótica. El personaje es un hijo que adora a su madre fallecida, a través de los retratos que la tía, la hermana fea, le muestra obsesivamente, en vano intento de liberar su complejo físico. Otro romance entre una persona y un espectro, que se cruza, esta vez, con el idilio entre el padre ebanista y la madre muerta, a cuyo luto, de muchos años, consagra un enorme baúl en el que preservará, intacto, el vestido nupcial de la amada. En ambos amores, el de Jenofonte y el de Filonús, predomina la contención del tacto, el dominio de los intercambios físicos, como recursos de una sensualidad tentativa, misteriosa, intangible.

La entrega a la palabra de los personajes de La noche del Aguafiestas hace de esta novela un remanso en la literatura cubana de hoy, tan dada al uso instrumental del lenguaje, al abuso del estilo con fines públicos. No en balde este libro de sutil ficción ignora las aprensiones del campo intelectual y nos ofrece una narrativa bibliófila, que reparte sus tributos entre raros autores franceses, como Emile Faguet y Benjamin Constant, y clásicos cubanos, como José Lezama Lima y Virgilio Piñera. En La noche del Aguafiestas, los homenajes a estos dos genios tutelares de la literatura de Antón Arrufat, están bien repartidos. Piñera merece varias alusiones al paso y una parada en el envenenamiento, por papaya, de Clitemnestra Plá, la madre de Electra Garrigó. Lezama, por su lado, recibe ofrendas implícitas como la del discurso erótico sobre las frutas, tomado de Oppiano Licario, o la cita del poema "Una oscura pradera me convida" (44-50).

La bibliofilia de La noche del Aguafiestas lleva el arte de la conversación de Antón Arrufat a una zona donde se borran las fronteras entre lo hablado y lo escrito. Así como en La caja está cerrada, el repertorio del habla remitía a la oralidad doméstica o colegial del mundo santiaguero de la República, La noche del Aguafiestas reconstruye el universo poco conocido de la sociabilidad letrada de la Revolución, en el que las lecturas se adueñan del diálogo. Lo leído aparece en esa literatura como un trofeo que debe ser exhibido, unas veces con discreción, otras con pedantería, pero siempre con la elegancia de quien ha decidido afirmarse social y políticamente por medio de la erudición. Arrufat y sus personajes serían casos ideales para explorar una sociología del saber en la Cuba socialista.

Revista Iberoamericana, Vol. LXXIX, Núm. 243, Abril-Junio 2013, $415-430$
ISSN 0034-9631 (Impreso) 
El tránsito entre el arte de la conversación de la primera y la segunda novela se comprende mejor repasando textos intermedios como las prosas de De las pequeñas cosas (1997) o Ejercicios para hacer de la esterilidad virtud (1998) y los poemas del cuaderno El viejo carpintero (1999). De las pequeñas cosas es un libro "bellísimo", como dijera sin remilgos Andrés Trapiello en el prólogo a la edición de Pretextos (1). Apareció en la colección de "narrativa” de esa editorial valenciana y en algunas notas biográficas de Arrufat aparece como un volumen de "relatos", pero se trata de un libro de ensayos, en la mejor tradición del género, la que viene directamente de Montaigne. A diferencia de Ejercicios para hacer de la esterilidad virtud, que se acerca al divertimento narrativo, al estilo de Cortázar o el propio Piñera, De las pequeñas cosas es la bitácora de un bibliófilo: un cuaderno de viñetas que, desde la herencia de Montaigne, desemboca en una prosa híbrida, entre ensayo, memoria y ficción, similar a la que hoy escriben autores como Claudio Magris o Enrique Vila Matas.

Arrufat relee a Villaverde, a Del Monte, a Bachiller y Morales, a Casal, a Martí, a Ortiz, a Guerra y, naturalmente, a Piñera, con el propósito de diseñar una cartografía literaria e histórica de La Habana. Pero también relee a Carroll, a Valéry, a Cocteau, a Proust, a Kafka, a James, a Gide, a Machado, siempre en busca de las conexiones occidentales de la isla. "El encuentro", "La glorieta” y “Trazo del jardín” son piezas memorables, en las que un refinado campo referencial de alta literatura se pone a disposición de evocaciones personales y urbanas, logrando una urdimbre delicada y, a la vez, firme de representaciones literarias de la ciudad.

En De las pequeñas cosas y Ejercicios para hacer de la esterilidad virtud hay una bibliofilia parecida a la de Piñera. Una bibliofilia moderna, entregada a la significación secular y laica, en más de un sentido, de las tradiciones letradas. En su gran biografía Montaigne a caballo (1996), Jean Lacouture vinculaba esa bibliofilia a la actitud del “ermitaño al acecho", es decir, el lector que escribe o, en su acepción contemporánea, el letrado de vanguardia, que hace de la erudición un acervo ligero y manipulable(192-230). Como Ricardo Piglia o Juan Villoro, Antón Arrufat es uno de esos escritores lectores que hacen de la lectura un tema de conversación de los textos. Esa exposición de lo leído no sólo se plasma en sus inteligentes ensayos sobre Gertrudis Gómez de Avellaneda, Julián del Casal y José Martí, que tanto deben a Piñera, sino en algunos poemas de El viejo carpintero (1999), donde asume su deuda con Baudelaire, Frost o Thompson.

La estirpe de Sainte-Beuve también expone sus modos en los ensayos dedicados a la historia de la literatura cubana que Antón Arrufat reunió en El hombre discursivo (2005) y Las máscaras de Talía (2009), su gran estudio sobre Gertrudis Gómez de Avellaneda. Como en los Retratos literarios del famoso crítico francés, Arrufat logra un trato familiar con los grandes escritores del pasado insular: José María Heredia y Julián del Casal, Gertrudis Gómez de Avellaneda y Ramón Meza, José Lezama Lima y, por supuesto, Virgilio Piñera. Lo que distingue esa idea de la crítica literaria como

\footnotetext{
Revista Iberoamericana, Vol. LXXIX, Núm. 243, Abril-Junio 2013, 415-430 ISSN 0034-9631 (Impreso) ISSN 2154-4794 (Electrónico)
} 
retrato familiar es la articulación de la interpretación estética y el apunte biográfico, el maridaje entre bios y grafía.

Esa idea de la literatura, como oficio y comunidad, como genealogía y tradición, logró sobrevivir a la hegemonía del marxismo-leninismo y el nacionalismo revolucionario sobre los discursos críticos de la isla. Con ella pudo Arrufat defender su linaje y, a la vez, reescribir la historia literaria de su país. Una historia que, como puede advertirse en ensayos como “Oyendo conversar a Lezama” (2006) o “Un olvidado de la República: Armando Leyva” (2010), no sólo está conformada por figuras canónicas, bien establecidas en los discursos críticos e historiográficos, sino también por raros, por escritores fantasmas que han sido relegados al olvido de las últimas generaciones y que Arrufat invoca como arqueólogo de las letras o como médium escribiente.

En su libro Los logócratas, George Steiner intentó caracterizar esa manera de entender la literatura moderna a partir de los casos de De Maistre, Heidegger, Boutang y Benjamin. A partir de una tradición que se remonta al Cratilo de Platón, Steiner afirma que los escritores "logócratas" son aquellos para los que no es el "hombre el que habla el lenguaje" sino el "lenguaje el que habla al hombre" (18). Al hacer de la conversación -"hablemos del conversar" dice uno de sus personajes- el centro de su escritura, Antón Arrufat se inscribe en esa logocracia. Por medio de Arrufat, un legado como el de Virgilio Piñera -de difícil asimilación, en una cultura machista, católica y marxista como la cubana, por sus acentos vanguardistas, laicos y heterodoxos- se erige en tradición. Arrufat hizo de Piñera un tema de conversación de su literatura y abrió el diálogo con su maestro a los más jóvenes escritores de la isla.

\section{OBRAS CITADAS}

Acosta Pérez, Alberto. "Poema por Virgilio Piñera”. Antología de la poesía cubana.

Tomo IV. Ángel Esteban y Álvaro Salvador, eds. Madrid: Editorial Verbum, 2002. Alberto, Eliseo. Esther en alguna parte. Madrid: Espasa Calpe, 2005.

Anderson, Thomas F. Everything in Its Place. The Life and Works of Virgilio Piñera. Lewisburg: Bucknell UP, 2006.

Arenas, Reinaldo. Antes que anochezca. Barcelona: Tusquets. 1992.

Arrufat, Antón. Cámara de amor. La Habana: Letras Cubanas, 1994. La divina Fanny. La Habana: Ediciones Unión, 1995. La huella en la arena. La Habana: Letras Cubanas, 1986. Las pequeñas cosas. La Habana: UNEAC, 1988. Qué harás después de mí. La Habana: Letras Cubanas, 1988. La tierra permanente. La Habana: Letras Cubanas, 1987. "Un olvidado de la República: Armando Leyva”. Libros del Crepúsculo. 11 enero 2011. <www.librosdelcrepusculo.com>. 13 enero 2011.

Revista Iberoamericana, Vol. LXXIX, Núm. 243, Abril-Junio 2013, $415-430$
ISSN 0034-9631 (Impreso) 
Las máscaras de Talía. Matanzas: Ediciones Matanzas, 2008.

“Oyendo conversar a Lezama”. Clarín. Revista de Nueva Literatura 11/66 (2006): 35-38.

El hombre discursivo. La Habana: Letras Cubanas, 2005.

La caja está cerrada. 1984. La Habana. Letras Cubanas: 2002.

La noche del Aguafiestas. La Habana: Letras Cubanas, 2000.

Los siete contra Tebas. La Habana: Unión, 1968.

El viejo carpintero. La Habana: Unión, 1999.

De las pequeñas cosas. Madrid: Pre-Textos, 1997.

Virgilio Piñera: entre él y yo. La Habana: Unión, 1994.

Mi antagonista. Madrid: La Fábrica, 2007.

Teatro: El caso se investiga. El vivo al pollo. El ultimo tren. La repetición. La zona cero. La Habana: UNEAC, 1963.

Ejercicios para hacer de la esterilidad virtud. La Habana: Ediciones Unión, 1997.

De las pequeñas cosas. Prólogo de Andrés Trapiello. 1988. Valencia: Pre-Textos, 1997.

Cabrera Infante, Guillermo. Mea Cuba. México: Vuelta. 1993.

Díaz, Duanel. Los límites del origenismo. Madrid: Colibrí, 2005.

Dinouart, Abate. El arte de callar. Madrid: Siruela, 1999.

Espinosa Domínguez, Carlos. Virgilio Piñera en persona. Miami: Término Editorial, 2003.

“Introducción al Homenaje a Virgilio Piñera”. Encuentro de la cultura cubana 14 (otoño 1999): 11-13.

Esteban, Ángel y Álvaro Salvador, eds. Antología de la poesía cubana. Tomo IV. Madrid: Editorial Verbum, 2002.

Estévez, Abilio. Inventario secreto de la Habana. Barcelona: Tusquets, 2004. La verdadera culpa de Juan Clemente Zenea. La Habana: Ediciones Unión, 1987.

Felipe, León. “¿Por qué los españoles hablan tan alto?” <http://www.contra-escritura. com//2012>. 17 ago. 2012.

Fowler, Víctor. “Otra lectura de Piñera: a propósito de un libro de Enrique Saínz”. Unión XIII/46 (abril-junio 2002): 16-28.

La maldición. Una historia del placer como conquista. La Habana: Editorial Letras Cubanas, 1998.

Heidegger, Martin. Carta sobre el humanismo. Madrid: Alianza, 2000.

Lacouture, Jean. Montaigne a caballo. México: FCE, 1999.

Leyva González, David. Virgilio Piñera o la libertad de lo grotesco. La Habana: Letras Cubanas, 2010.

López, César. “Truenos en el Olipo porque Virgilio Piñera ha muerto”. Antología de la poesía cubana. Tomo IV. Ángel Esteban y Álvaro Salvador, eds. Madrid: Editorial Verbum, 2002.

Revista Iberoamericana, Vol. LXXIX, Núm. 243, Abril-Junio 2013, $415-430$
ISSN 0034-9631 (Impreso) 
Molinero, Rita. Virgilio Piñera. La memoria del cuerpo. San Juan: Editorial Plaza Mayor, 2002.

Pérez, Jorge Ángel. Fumando espero. La Habana: Letras Cubanas, 2003.

Piñera, Virgilio. Algunas verdades sospechosas. La Habana: Ediciones Abril, 1992. Una broma colosal. La Habana: UNEAC, 1988.

La carne de René. Buenos Aires: Ediciones Siglo Veinte, 1952.

Cuentos completos. Madrid: Alfaguara, 1999.

Cuentos fríos. Buenos Aires: Losada, 1956.

Un fogonazo. La Habana: Letras Cubanas, 1987.

Las furias. La Habana: Espuela de Plata, 1941.

La isla en peso. La Habana: Ediciones Unión, 1998.

Muecas para escribientes. La Habana: Letras Cubanas, 1987.

Teatro inédito. La Habana: Letras Cubanas, 1993.

El viaje. La Habana, Letras Cubanas, 1992.

La vida entera. La Habana: UNEAC, 1969.

Dos viejos pánicos. La Habana: Casa de las Américas, 1968.

Ponte, Antonio José. El libro perdido de los origenistas. México D.F.: Aldus, 2002.

"Reclamaciones equivocadas a Virgilio Piñera". Extramuros 8 (enero-abril 2002): 1-3.

Proust, Marcelo. Contra Sainte-Beuve. Recuerdos de una mañana. Barcelona: Tusquets, 2005.

Saínz, Enrique. La poesía de Virgilio Piñera. Ensayo de aproximación. La Habana: Letras Cubanas, 2001.

Santí, Enrico Mario. Luz espejeante. Octavio Paz ante la crítica. México D.F.: Era, 2009.

Sarduy, Severo. "Pido la canonización de Virgilio Piñera”. Antología de la poesía cubana. Tomo IV. Ángel Esteban y Álvaro Salvador, eds. Madrid: Editorial Verbum, 2002.

Steiner, George. Los logócratas. México D.F.: FCE/ Siruela, 2007.

Sorel, Andrés. “Virgilio Piñera. ¿Una broma colosal?”. República de las Letras 114 (oct. 2009): 5-16.

Vargas Llosa, Mario. "La trompeta la Deyá”. Julio Cortázar. Cuentos. Madrid: Alfaguara, 1994. 19-20.

Vitier, Cintio. Lo cubano en la poesía. La Habana: Instituto del Libro, 1970. Cincuenta años de la poesía cubana. La Habana: Dirección de Cultura del Ministerio de Educación, 1952.

Diez poetas cubanos. La Habana: Ediciones Orígenes, 1948. Orígenes II/5 (primavera 1945): 47-50.

Rescate de Zenea. La Habana: Unión, 1987.

Revista Iberoamericana, Vol. LXXIX, Núm. 243, Abril-Junio 2013, $415-430$
ISSN 0034-9631 (Impreso) 